\title{
Legal dimensions of immigrant access to employment in Bulgaria: a contextual analysis
}

\begin{abstract}
This paper aims to illustrate the current legal landscape and practical challenges facing immigrants in Bulgaria as regards integration into the labour market. It determines that the challenges are significant and the current legal procedures specific, demanding and often confusing. Coupled with an ill-defined and incomplete formal integration policy and systematic disregard for the rights of asylum seekers, legal employment opportunities for many immigrants are extremely difficult to access. A contextualisation of current policy through historical analysis is offered following which contemporary legal requirements and restrictions placed on immigrants in Bulgaria are presented and examined. Positive and negative aspects of the Bulgarian legal approach are subsequently explored and areas of improvement highlighted, including practical steps towards the realisation of effective, fair and humane policy. Such policy not only respects the potential and necessary contribution that immigrant labour presents to the social and economic development of Bulgaria, but also shows respect for the common humanity and universal rights afforded all human beings regardless of citizenship.
\end{abstract}

Keywords: Bulgaria, migration politics, immigrant labour, free movement of labour, access to employment, reform, integration, UN Conventions

\section{Introduction}

This article aims to illustrate the current legal landscape and practical challenges facing immigrants in Bulgaria as regards integration into the labour market. These challenges are significant and the current legal procedures specific, demanding and often confusing. Coupled with an ill-defined and incomplete formal integration policy and systematic disregard for the rights of asylum-seekers, legal employment opportunities for many immigrants are extremely difficult to access. Many are left no choice but to enter the informal economy where abuse, exploitation, fragile circumstances and potentially dangerous and illegal work characterise the unregulated environment.

The paper will proceed in three parts. It will begin, in Historical background, with a contextualisation of current policy through a summary of previous experience and the history of state initiation of, and response to, migration and minority politics. The second section, Current legal structures for immigrant access to employment, will introduce and discuss contemporary legal requirements and the restrictions placed on immigrants in Bulgaria. Issues, challenges and recommendations details the positive and negative aspects of the Bulgarian legal approach and aims briefly to suggest areas of improvement and practical steps towards the realisation of effective, fair and humane policy. Such policy would not only respect the potential and necessary contribu- 
tion immigrant labour presents to the social and economic development of Bulgaria, but would also show respect for the common humanity and universal rights afforded all human beings regardless of citizenship.

It is important to note that successful integration is a holistic and multi-dimensional process demanding consideration of a number of perspectives from both host and minority populations. The following examination explores the economic and legal obstacles but only in tandem with broader social considerations can effective and substantive progress be actualised.

\section{Historical background}

Few nations in history have experienced such intensive regional scrutiny on market and labour policy as European Union accession countries or new member states. Fewer still have experienced the added pressures associated with hosting an EU 'external land border'. Market access, support for human rights, geopolitical stability and any number of other topics are regularly touted as the central foci of European governments towards new accession states but, without fail, issues of migration are rigorously and exhaustively politicised, debated and publicised in an effort to reinforce (and occasionally question) notions of control on the European 'frontier'. The demands on regulation are significant, particularly in the face of a rapidly re-adjusting economy and state structure, such as that brought about through dramatic social and political change - including the transition from communism to democracy and the development of EU standard 'free market' policies.

Underscored in these international debates are subtle, and occasionally insidious, notions of access and economics. Free movement and employment access within the Union are implied (if not actual ${ }^{1}$ ) central tenets of EU membership and citizens of new member states may, for the most part, reside and work in any other member state. The implications for those not holding citizenship, however, are not only more severe but also more invisible. Many immigrants in Bulgaria, frustrated by impossible legal obstacles, are forced to leave the country, to face extended and inhuman detention and deprivation of their rights or to enter the informal economy or worse.

Bulgaria, one of three countries sharing a land-bridge to Asia at the base of the Black Sea, has long experienced migration flows but maintains no substantive political or academic tradition of analysis concerning this phenomenon, while recent research has focused almost exclusively on issues of emigration. The post-communist 'discovery of immigration' (Krasteva, 2006: 26) is still in its early stages and historical context is critical to understanding the current state of legal and social conceptions of immigrants.

From the early days of the Ottoman occupation to independence (with the help of the Russians) in 1878 and continuing through to the Second World War, the dissolution of the 'Soviet Bloc', the Balkan Wars and up to the current day, Bulgaria has

1 In 2006, the European Commission expressed 'strict conditions' on Bulgarian and Romanian access to labour markets upon accession. The United Kingdom took these restrictions further, announcing in 2006 that new citizens of Europe from Bulgaria and Romania would be 'restricted to existing quota schemes to fill vacancies in the agricultural and food processing sectors.' Home Office of the government of the United Kingdom (2006) Controlled Access To UK Labour Market For New Accession Countries. 
struggled with strong and persistent conceptions of national identity, popular migration and a far-reaching diaspora (see: Loizos, 1999; Vassilev, 2001; Helton, 1992; Skran, 1998; Dacyl, 1990; Mintchev, 1999). After 1950, Bulgaria saw two large-scale exodus movements of Turkish Bulgarians. The first, between 1950-1952, saw nearly 160000 ethnic Turks cross into Turkey. Subsequently, during the decade between 1982-1992, 350000 ethnic Turks 'fled from collective oppression, enforced Bulgarianisation and economic problems' although 150000 of these are reported to have subsequently returned (Fassman and Munz, 1994: 532).

Bulgaria is an ethnically plural state, tracing clear and, at times, xenophobic ${ }^{2}$ differentiating lines around minority 'migrant' communities. ${ }^{3}$ Communist-era policies reinforced notions of collective uniformity, often subjugating minorities. Indeed, the communist government worked to:

Shore itself up by manipulating the majority's nationalist sentiments... [it] had created a polarizing conflict along ethno-religious lines by subjecting the Muslim Turkish minority in Bulgaria to a campaign of cultural and linguistic assimilation.' (Vassilev 2001: 37).

This policy of forced assimilation amounted to a persecution of Muslim Bulgarian nationals, as demonstrated through the case of S. Kalaydsiev, J. Anguelov, A. Mladenov v. Decision 13/1985 of the Athens Court of Appeal Council (Helton, 1992: 381382). The advent of democracy threatened to inflame ethnic turmoil when the forced assimilation policy - termed the 'national revival' campaign under the Zhivkov regime in the mid-1980s - formally ended and minority rights were officially (if not practically) restored (Vassilev, 2001: 37) in 1989.4 No official recognition of multiculturalism currently exists, ${ }^{5}$ and increasingly popular nationalist parties in Bulgaria have denied the existence of Bulgarian ethnic minorities within the country in an effort to create a nationalist fervour (Vassilev, 2001: 37). The effects of this are socially dramatic, presenting extreme difficulties for, resentment towards and suspicion of immigrants.

However, Krasteva identifies three exceptions to the 'strictly controlled' movements to, from and within Bulgaria during communist years. Perhaps not surprisingly, these were based in a reassurance of political advantage (see: Mintchev, 1999: 148) and included the emigration of Bulgarian Turks to Turkey, the immigration of students:

2 See Iliana Savova, as cited in Hershman, G (2007) 'The Other Expats: Bulgaria's forgotten foreigners languish in limbo and the state seems indifferent' Vagabond.

3 This is perhaps most clearly demonstrated through treatment towards the Roma population and Bulgarian Turks - both considered, to differing degrees, as 'migrant' minority communities.

4 According to Vassilev, 'The decision to renounce the "revival process", made public on 29 December 1989, sparked nationwide protests by Bulgarian nationalists to resist the new policy.' These protests included slogans such as 'Bulgaria for the Bulgarians' and objected to what they called 'The government's "policy of national nihilism".' Vassilev, R. V (2001) 'Post-Communist Bulgaria's Ethnopolitics' The Global Review of Ethnopolitics 1: 37-53.

5 'The Bulgarian government does, however, publicly recognise the existence of a Muslim Turkish minority in Bulgaria and, although not officially registered as such, the ethnic Turkish-dominated Movement for Rights and Freedoms (MRF) [is] the largest and most influential ethnic minority party in Bulgaria' ibid. 
With the specific purpose of providing higher education to left-wing intellectuals as part of a long-term strategy for the preparation of world revolution,

and the immigration of sympathetic activists from neighbouring countries (Krasteva, 2006: 26).

These were very specific movements with geopolitical goals, but economics ultimately provided for a fourth migration. Not unlike predominant western trends, the appeal of labour-related immigration led to the loosening of otherwise extremely restrictive conditions and Bulgaria accepted 'guest worker' (gastarbeiter) Vietnamese in the 1980s (European Intercultural Workplace, 2006: 18; Krasteva, 2006: 26).

Two significant modern events have deeply shaken established efforts towards a near-total restriction of migration. The first is the onset of the 'changes' and the advent of democratic governance in 1989; and the second is accession to the EU in 2007. According to Mintchev:

After the fall of the Berlin Wall, considerable changes occurred in the mechanical movement of the Bulgarian population. During the period 1989-1997, over 650 thousand people emigrated from the country permanently. According to data from 1994, for the period 1986-1992, Bulgaria exported 19.6 million years of 'life' and 11.4 million years of 'labour' (1999: 148).

The onset of EU membership represents the second stage in an evolving process of 'opening up' Bulgaria not only to foreign economic investment (and the subsequent business-related migration of people and monies) but also to Bulgarian emigration at an unprecedented level. According to current statistics produced by the European Union, projections of negative population growth in Bulgaria due to emigration surpass any other country in Europe all the way through to 2050, the year beyond which the research group ceases projection (Eurostat, 2004). This level of exodus has significant consequences for the labour market. Remittances represent a potentially immediate benefit to the Bulgarian economy, but the cost of highly-skilled emigration is high (Markova and Reilly, 2006) ${ }^{6}$ and of great economic concern to the Bulgarian government (Chompalov, 2000: 3). Simultaneously, the necessity for qualified labour in Bulgaria consequently increases in an environment which is less attractive to citizens tempted by promises of higher wages in newly-accessible western European markets. At the same time, low-skilled labour in the EU market represents a potential benefit to Bulgarians unable to find satisfactory wages for the same work at home, again creating gaps to be filled. Bulgaria needs immigrants.

\section{Current legal structures for immigrant access to employment}

\section{General overview of the legal framework concerning migration policy in Bulgaria}

Bulgarian legislation related to the integration of migrants into the labour market, indeed Bulgarian legislation in the sphere of migration in general, has experienced and

6 It is important to note that lack of substantive data and 'interpretive problems' affect discussions surrounding ideas of the 'brain drain' on Bulgarian economic development. See: W. T. Bagatelas and J. Kubicová (2003) 'Bulgarian emigration - a closer look' South-East Europe Review 4: 27-36; Mintchev, V (1999) 'External migration and external migration policies in Bulgaria' South-East Europe Review 2: 123-150. 
continues to experience dynamic adjustment and change since the early 1990s. This adjustment has notably intensified during recent years with the push towards the harmonisation of Bulgarian laws and norms with international and European standards. In January 2007, Bulgaria became an EU member state and began hosting an external border of the EU. Together with a number of positive adjustments following this event, accession has demanded stronger and more repressive state policies on the restriction of movement and regulations on immigration. This process has been justified in the name of concerns over security and the combating of illegal activities. In a search for the crucial balance between perceived state interest in the regulation of migration and its obligation to respect the human rights of all people - including migrants - Bulgaria is in the initial steps of formulating and implementing just, appropriate and comprehensively sustainable responses to the opportunities and challenges of migration, while its current systems demand significant improvement.

The general legal framework of migration regulation in the country is comprised of a series of norms, allocated at Constitutional, legal and sub-legal level, which regulate the rights and obligations of different migrant groups as well as the specific regulatory procedures, together with the structure and function of the corresponding institutions.

Article 26(2) of the Constitution of the Republic of Bulgaria (henceforth, the Constitution) ensures all foreigners the rights proceeding from the Constitution except those which specifically require Bulgarian citizenship. ${ }^{7}$ Article 19 , which details economic activity, declares the Bulgarian market to be based on free economic initiative and suggests that the economic activity of foreign persons shall enjoy the protection of the law. The right to equality before the law, however, as presented in Article 6(2), applies only to citizens. Citizenship, as elaborated in Article 25(1), shall be granted to:

Anyone born of at least one parent holding Bulgarian citizenship, or born on the territory of the Republic of Bulgaria, should he not be entitled to any other citizenship by virtue of origin. Bulgarian citizenship shall further be acquirable through naturalisation.

Article 22 of the Constitution, the so-called 'foreigners clause', restricts foreign access to ownership of land and the acquisition of certain rights. However, this article was amended in 2005 by the Treaty concerning the Accession of the Republic of Bulgaria to the European Union so as to provide for the legal ownership of land by foreigners and foreign legal persons. The revised article entered into legal recognition on 1 January 2007 as Bulgaria entered the European Union.

A small number of national laws are in place which further regulate the status of foreigners in Bulgaria. Some of these include: the Law on Foreigners in the Republic of Bulgaria; the Law on Asylum and Refugees; the Law on Entering, Residing and Leaving the Republic of Bulgaria of European Union Citizens and Members of their Families; the Law on Protection against Discrimination which protects 'all individuals on the territory of Bulgaria'; the Law on the Encouragement of Employment; the

7 Article 26(2) of the Constitution declares that: 'Foreigners residing in the Republic of Bulgaria shall be vested with all rights and obligations proceeding from this Constitution, except those rights and obligations for which a Bulgarian citizenship is required by this Constitution or by another law' (Constitution of the Republic of Bulgaria (1991), 39th National Assembly of the Republic of Bulgaria). 
Law on Bulgarian Identification Documents; the Law on Bulgarian Citizenship; the Law on Fighting the Illegal Traffic of People. These laws provide for some clarification - and some confusion - of the legal provisions; however, Bulgaria remains without an articulated and comprehensive formal policy concerning non-citizens present within the territorial bounds of the state.

At the sub-legal level, the Bulgarian state employs a number of regimes for the control and maintenance of migration systems through the application of the Law on Foreigners in the Republic of Bulgaria. Demonstrations of such mechanisms are tangibly evident in visa controls (the issuance and denial thereof, as well as the determination of duration and access); residency and employment permissions; permits for non-profit activity; permissions for economic and investment purposes; and so forth.

The most disturbing demonstration of the sub-legal mechanisms which affect immigrants is, without question, the use of administrative detention for the physical restriction of non-citizens (see: Ilareva 2007a, 2007b; Hershman, 2007). The detention of foreigners has a long history in Bulgaria - with cases of prolonged airport detention (sometimes exceeding many months) reaching into the early 1990s (Hughes and Liebaut, 1998). Even more disturbing has been the documented trend towards a practical obfuscation of the asylum process and the systematic denial of internationallyrecognised rights and procedures. The blocking of the submission of asylum claims and the forcible deportation of foreigners has, on multiple occasions, amounted to refoulement, a violation of international law under Article 33 of the 1951 Convention relating to the Status of Refugees and Article 3 of the 1984 Convention Against Torture and Other Cruel, Inhuman or Degrading Treatment or Punishment which Bulgaria ratified in 1993 and 1986 respectively.

Similarly divided into hierarchical structure are the various 'categories' of immigrants themselves, ranking from those recognised with legal rights and access to those undocumented and unrecognised by the Bulgarian state. These different immigrant categories can be roughly separated into four main groups:

- immigrants with short-term or long-term (prolonged or permanent) permits to stay

- refugees ${ }^{8}$ and foreigners with humanitarian status, temporary protection or asylum protection

- asylum seekers $^{9}$

- undocumented or semi-documented immigrants.

8 The term 'refugee' has a very specific meaning in international law and the Bulgarian state is obligated to this definition: a refugee is any person who 'Owing to well-founded fear of being persecuted for reasons of race, religion, nationality, membership of a particular social group or political opinion, is outside the country of his nationality and is unable, or owing to such fear, is unwilling to avail himself of the protection of that country; or who, not having a nationality and being outside the country of his former habitual residence as a result of such events, is unable or, owing to such fear, is unwilling to return to it" Article 1(A)(2) Convention relating to the Status of Refugees (1951) Geneva, United Nations Conference of Plenipotentiaries on the Status of Refugees and Stateless Persons convened under General Assembly resolution 429 (V) of 14 December 1950 as amended by the 1967 Protocol relating to the Status of Refugees.

9 Asylum seekers are those people who have entered the territory of Bulgaria with the intention to request formal protection from persecution under the definition of 'refugee' above. 
The corresponding institutions dealing with the administrative organisation of migration management are:

- Ministry of External Affairs and its consular units, where entry visas are issued

- Ministry of the Interior, responsible for border control and internal regulation regarding the processing of migrants. This regulation affects permits to stay, the issue of formal identification documents and the exercise of compulsory administrative measures

- Ministry of Labour and Social Policy, where work permits for foreigners are issued

- State Agency for Refugees with the Council of Ministers, which regulates the different forms of protection offered to asylum seekers and takes decisions regarding the granting of particular status

- Ministry of Justice and the President's Office, where approval for Bulgarian citizenship and for asylum by Order of the President are issued. These organs are also responsible for granting permissions for non-profit activity.

These bodies function under specific regulation towards the management of immigration in Bulgaria. An essential part of immigrant integration in Bulgaria is conditioned by the regulation of entry and stay regimes for foreigners, arranged in the Law on Foreigners in the Republic of Bulgaria (henceforth, the 'Law on Foreigners'); the Law on Entering, Residing and Leaving the Republic of Bulgaria of European Union Citizens and Members of their Families (henceforth, the 'EU Citizens Law'); and the Law on Refugees and Asylum (henceforth, the 'Law on Refugees').

There are two main entry and stay regimes on the territory of Bulgaria: short-term stay and long-term residence.

Short-term stay is not of great concern for the purposes of labour discussion since it permits stays of up to ninety days in the country for a period of six months and does not grant the possibility of engagement with the labour market. Non-EU citizens with short-term stays must enter the territory of Bulgaria with ' $\mathrm{C}$ ' category visas issued at a diplomatic or consular mission of Bulgaria abroad. Such a visa is not needed for citizens of the EU or other countries which are parties to specific international or inter-state agreements.

The long-term residence regime applies in regard to foreigners who want to reside continuously (with a permitted period of stay of up to one year) or permanently (with a permitted indefinite period of stay) in the Republic of Bulgaria. The legal procedure for being granted long-term residence has been greatly facilitated for citizens of the EU with the entry into force of the EU Citizens Law. The main relief in this case comes from dropping the requirement for EU citizens pursuing employment to enter in the country with the otherwise-required type ' $D$ ' visa. ' $D$ ' visas are, however, still required for foreigners of non-EU citizenship, including non-EU citizen family members of Bulgarian citizens. The grounds for issuing such a visa and obtaining longterm residence are explicitly referenced in Articles 24 and 25 of the Law on Foreigners $^{10}$ and can be applied to different individual intentions, such as: a labour contract; commercial activity; investment; non-profit activity; marriage; and education.

10 See Appendix. 
The regimes of entry described above are not applied - or, at least, should not be applied - to the category of asylum seekers who ought to enjoy a privileged right of access to the territory and the right not to be returned to a place where their lives or freedom are threatened. These rights are inviolable ${ }^{11}$ and detailed in the Law on Refugees.

\section{Legal rights to work for immigrants in Bulgaria}

For the purpose of exploring immigrant integration into the Bulgarian labour market, we will look more closely at the rights that immigrants, refugees and asylum seekers currently enjoy in the country and how effectively these rights are applied. A considerable step forward is - as mentioned above - the facilitated procedure for granting continuous and permanent long-term residence in Bulgaria for EU citizens via release from the category ' $\mathrm{D}$ ' visa requirement and additional complications.

The reality in Bulgaria, however, is that the largest flow of immigrants is not comprised of EU citizens but, rather, citizens of non-EU countries and stateless people. The result is that access to the market for large groups of migrants is still regulated by complicated, cumbersome and unwieldy visa regulations arranged in the Law on Foreigners. In order for a non-EU, non-asylum seeking foreigner to work on a labour contract in Bulgaria, s/he must first receive a labour permit from the Ministry of Labour and Social Policy. Application for this labour permit is made by the local employer, whose foreign employees should not comprise more than $10 \%$ of the total number of employees and who should be paid a minimum salary significantly disproportionate to the minimum salary received by Bulgarian employees. In addition, the process is burdened by the triple-level procedure, which requires consideration of the application once before the Ministry of Labour and Social Policy in order to receive the work permit; once before a diplomatic and consular mission of Bulgaria abroad in order to apply for a 'D' category visa; and, lastly, before the Ministry of the Interior for a permit to stay. ${ }^{12}$

The rights of refugees and asylum seekers are detailed in the Law on Refugees. According to Chapter IV, Article 32 of the Law on Refugees, foreigners granted legal

11 The rights described are protected in Bulgarian and international law, but there is evidence that they are not currently respected in Bulgaria. See Amnesty International (2007) Bulgaria. Europe and Central Asia: Summary of Amnesty International's Concerns in the Region: January - June 2007. Amnesty International; Ilareva, V (2007b) 'Bulgaria's treatment of asylum seekers' Forced Migration Review 29: 60-61.

12 To provide an example from our own experience: the pursuit of all the mentioned requirements for hiring a US citizen as Project Manager of the Legal Clinic for Refugees and Immigrants have been considerably difficult and, six months from initiation, the LCRI remains at the initial stage of obtaining a work permit from the Ministry of Labour and Social Policy. This stage alone has required international co-operation on the part of numerous governmental, personal and institutional entities on four continents. Upon the fulfilment of the initial requirements, the application was deemed to require additional support demanding the extra submission of additional documentation of a similar difficulty to acquire. This process is financially, practically and often temporally impossible for many applicants, practically locking out those organisations and individuals without the resources or connections necessary for successful application submission. Such obstacles open the door for corruption in the procedure. 
status (refugee or humanitarian) ${ }^{13}$ have equal rights to Bulgarian citizens, excluding those rights which specifically require Bulgarian citizenship. The result is that access to the labour market is, legally if not practically, equal to those of Bulgarian citizens.

In order to facilitate refugee access to employment - and thereby encourage integration - the government established a national plan-for-action programme for the integration of refugees in 2002, to be funded by the state and implemented by the State Agency for Refugees in co-operation with governmental and non-governmental organisations. ${ }^{14}$ This programme includes language and professional education, as well as the facilitation of contact with prospective employers. However, the places available are restricted and state funding is not sufficient, in spite of the expectation that the National Programme for 2008-2010 envisages an increased budget. The nongovernmental sector taking a significant role in this sphere is of crucial importance.

Regrettably, the law grants less access and fewer rights to asylum seekers, despite many of them spending months if not years awaiting the results of their asylum applications. According to Article 29(3) of the Law on Refugees, asylum seekers in an ongoing procedure before the State Agency for Refugees:

Shall have the right to access the labour market, provided that the proceedings are not finalised within up to one year after the submission of the application for status due to reasons out of his/her control.

In practice, this means that people seeking asylum do not have access to the labour market or to programmes for integration when these are potentially most needed.

An additional difficulty here comes from complications and inconsistencies in the application of the law. For example, in order for the initial protection prescribed in the Law on Refugees to function, one needs to be recognised as an asylum seeker. Recent changes in the Law on Refugees have seen to it that this happens with the registration of an asylum application, not with its submission. In Bulgaria, the time between submission and registration has no limit, resulting in tremendous hardship for asylum seekers as many are obliged to remain indefinitely without legal recourse to basic rights and protection while awaiting 'registration'. During this limbo period, asylum seekers are without any legal status in the country and are correspondingly without

13 Pursuant to the Law on Refugees Art. 8, Para. 1, a status of refugee in the Republic of Bulgaria shall be granted to a foreigner who, owing to a well-founded fear of being persecuted for reasons of race, religion, nationality, membership of a particular social group or because of political opinion, is outside the country of his origin, or owing to such fear, is unwilling to avail himself of the protection of that country. Pursuant to Art. 9 of the Law on Refugees, humanitarian status shall be granted to foreigners who have been compelled to leave their country of origin because in this country there is a real danger of severe aggression such as: death penalty or execution; torture, inhuman or degrading treatment or punishment; severe and personal menaces against the life and personality as a civil person by reason of violence in the case of internal armed conflict. Humanitarian status shall be granted on a temporary basis until the time of the ending of the reasons for its granting.

14 See the National Programme for Integration of Refugees in 2005-2007, available at: http://aref.government.bg/?cat $=25$ 
access to the labour market, livelihood support and medical care, and are in danger of being deported in violation of their internationally-protected rights against refoulement. ${ }^{15}$

\section{Immigrants not permitted access to the labour market}

Legal access to the labour market, as well as to any kind of proper activity in Bulgarian society, is granted only to foreigners with legalised stays in the territory. However, the number of undocumented ${ }^{16}$ and semi-documented immigrants in Bulgaria is significant and greatly outnumbers those with legal stays. Undocumented immigrants comprise a dynamic group, but many can demonstrate a continuous presence within the territory of the country. It is, therefore, in the interest of the Bulgarian state and economy to establish methods to facilitate the enjoyment of basic rights and livelihood strategies - including employment. Bulgaria is not a signatory to the International Convention on the Protection of the Rights of All Migrant Workers and Members of Their Families, and has made little progress to recognise its obligations towards the realisation of the basic rights elaborated in the Universal Declaration of Human Rights which apply to all people, regardless of their legal status, and which, in Article 23, articulates a universal right to work and to protection against unemployment.

\section{Issues, challenges and recommendations}

The following section details practical challenges to the above constructions through the experience of the Legal Clinic for Refugees and Immigrants (LCRI), an independent non-profit organisation that provides training in refugee, migration and human rights law to Bulgarian students and utilises their skills via the provision of legal aid to immigrant clients. ${ }^{17}$ The LCRI is unique in Bulgaria as it is the only organisation which trains university students by providing them with practical experience ${ }^{18}$ and which assists immigrants with a wide variety of concerns and challenges.

15 The principle of non refoulement is the cornerstone of international refugee and asylum law. It prohibits the return of refugees and asylum-seekers to countries in which they may face persecution or any form of torture, cruel, inhuman or degrading treatment. The principle is articulated in Article 33 of the 1951 Convention relating to the Status of Refugees and is reinforced in a great number of instruments of international scope. It is widely considered a principle of customary international law.

16 The term 'undocumented', rather than 'illegal', is appropriate as it is impossible, in legal terms, for a person to be 'illegal' but rather, in the concrete cases, they may not dispose of some of the necessary documents according to the requirements of the local migration legislation. Ilareva, V (2007a) 'Immigration Detention in International Law and Practice: In Search of Solutions to the Challenges Faced in Bulgaria' Statewatch.

17 For more information on refugee and immigrant legal clinics see: Acer, E (2004) 'Making A Difference: A Legacy of Pro Bono Representation' Journal of Refugee Studies 17: 347366; Harrell-Bond, B (forthcoming 2008) 'Starting a movement of refugee legal aid organizations in the south' International Journal of Refugee Law 19: 729-735.

18 The LCRI works with over 100 clients at any given time and the need for legal aid is an overwhelming one, as noted by the United Nations High Commissioner for Refugees UNHCR BO Sofia (2002) Bulgaria Country Operations Plan 2003 Sofia: United Nations High Commissioner for Refugees. Meanwhile, the lack of resources available to provide and expand legal assistance is a 'core problem' in Bulgaria, ibid. 


\section{Non-EU immigration}

Concerning non-EU immigrants and the process surrounding category 'D' visa status entry, Bulgaria could benefit greatly from a streamlining of the procedure and from the facilitation of processes so as to ease access. The demands placed upon applicants are often insurmountable, shutting out qualified and willing foreign contributors to the Bulgarian economy and labour market. Bias towards larger employers built into the category 'D' visa requirements de facto excludes the possibility of small organisations (those with fewer than ten employees) from legally hiring foreign labour. Similarly, the costs attached to the process present an impossible obstacle to many start-up and small employers. Recognition of the unique economic value intrinsic in business and organisational diversity should provide the impetus to facilitate the growth of these sectors through the facilitation of foreign access.

\section{Detention}

The tendency towards increasing numbers of asylum seekers and immigrants being deprived of their liberty through the concept of administrative detention is the single most disturbing trend in Bulgaria as regards migration since it threatens fundamental concepts of human freedom and blocks access to the labour market and the making of quality contributions to the Bulgarian social and economic environment. This procedure creates and maintains physical barriers to social and economic integration and reinforces notions of 'otherness' and false conceptions of criminality. It simultaneously raises alarming human rights concerns.

Detention is executed through imposed orders for the deportation of foreigners due to unsettled legal status or threats to national security, but is wrought with procedural inaccuracies and often applied in violation of international law (Ilareva, 2007a). It is alarming that asylum seekers are treated on an equal basis with undocumented immigrants and are detained on orders for deportation, in spite of the Bulgarian Penal Code and international law providing asylum seekers with special protections in terms of 'illegal' entry. Due to the delay in the official registration of submitted requests for asylum, applicants often wait for months before their procedure in front of the State Agency for Refugees even begins, a precarious time during which they are not 'formally' recognised as deserving of the protections granted to asylum seekers even though they have formally declared their intention to claim asylum (Ilareva, 2007b).

Additional complications in regard to administrative detention relate to an existing vacuum in the Law on Foreigners as regards temporal limitation. The result is that hundreds of immigrants are detained for months if not years due to a lack of co-operation from consular bodies, statelessness or through simple bureaucratic mishap and administrative malpractice (Ilareva, 2007b). Those detained remain at the provision of the state rather than contributing to the economic development of Bulgaria through participation in the labour market. Statistics are hard to find, but it is clear that detention is expensive; a member of the Migration Directorate has cited a cost of 12.20 leva per detainee per day (Petkov, 2007), but estimates often range above the 20.00 leva mark. In another EU member state pursuing similar strategies, the cost of detaining 
one person for one month 'far exceeds' the average monthly household income (Ilareva, 2007a: 22-23). ${ }^{19}$

There exist structures in Bulgaria for the supervised release of detainees through local guarantors, but the opportunity to find a guarantor while detained is minimal to non-existent due to physical restrictions on social contact, particularly for people without pre-established connections in Bulgaria, as is the case with many asylum seekers and other migrants. In the case that a guarantor is found, the financial burdens and strict demands of the Migration Directorate can be oppressive. The result is that this option is out of the reach of many would-be guarantors. Additionally, the daily requirements placed on 'guarantor released detainees' to submit themselves daily to the Migration Directorate place an additional financial burden on guarantors and make impossible any substantive contribution to Bulgarian society through volunteering, informal education, social involvement or other constructive pursuits. Additionally, those released under this programme receive no formal recognition of their status in Bulgaria, forfeit any access to medical care and are not permitted to access the labour market. The result is a reliance on the informal economy, where medicines are unregulated, mislabelled and extremely dangerous, and where labour conditions are exploitative and unreliable. Participation in this economy is an illegal activity, criminalising people who have no other access to live-saving medications or monies to sustain themselves and, at times, their families.

Bulgarian detention practices seriously compromise positive developments in the sphere of immigration and require immediate and substantive review. This review should focus on human rights concerns, access to integration (even if temporary) and the temporal limitations on administrative removal of freedoms (Ilareva, 2007a, 2007b). Changes should be implemented to bring Bulgaria in line with and to surpass European best practice so as to demonstrate exemplary leadership in the treatment of immigrant populations.

\section{Refugee integration}

It is commendable that Bulgaria has recognised the inadequacy of current legislation to fulfil its stated commitment to refugees holding status as such in terms of rights and services, ${ }^{20}$ but practical steps towards remedy have been slow to materialise and current commitments are weakly worded. In terms of efforts to assist in language acquisition - a critical point in integration and in capacity to access the labour market the government is committed to 'discuss' the 'possibility' of providing compulsory lan-

19 Simultaneously, state interest in maintaining detention centres may be based on increasing employment rates of citizens. Ilareva points out that ' $[\mathrm{A}]$ detention center creates jobs and business opportunities for many people.' The question then arises as to whether 'The deprivation of liberty truly serves higher national interests or... are [there] too many particular interests involved?' Ilareva, V (2007a) 'Immigration detention in international law and practice: in search of solutions to the challenges faced in Bulgaria' Statewatch.

20 According to the National Programme for Integration of Refugees 'Some of the existing legal acts in the field of social care, health care, education, accommodation and etc. need to be specified, expanded or changed in order to guarantee the full equality of the rights and services for refugees.' State Agency for Refugees with the Council of Ministers (2005) National Programme for Integration of Refugees in 2005-2007 http:// aref.government.bg/?cat $=25$. 
guage training for refugees with newly-granted status (State Agency for Refugees with the Council of Ministers, 2005).

The 2005-2007 Bulgarian programme for the integration of refugees is a document which is almost entirely forward-looking rather than one grounded in solid policy. It elaborates on potential future courses of action without strict commitments to them. Regarding labour access, for example, it states that:

A comprehensive approach should be developed in order to successfully provide employment to refugees. This includes Bulgarian language education, individual assessment of the professional knowledge and abilities, directing (sic) to vocational training and prequalification courses and helping (sic) with finding work. The refugees should provided (sic) assistance and help with developments (sic) of small business projects. (State Agency for Refugees with the Council of Ministers, 2005)

No report on developments since the initial drafting of this programme is publicly available and there exists some confusion among assistance organisations about the details of the actual services provided and how these can be accessed. The state has, however, informally declared that it pays, for 'courses and accommodation' for those on the programme, a sum of 360 leva per participant. ${ }^{21}$ Whether there are any practical obstacles to application for and acceptance on the programme, or any qualifications surrounding decisions to admit, is unclear. ${ }^{22}$

Facilitation of access needs to be made available to all refugees and information regarding the programme ought to be widely disseminated in multiple languages. Additionally, state commitment to:

Involvement on the part of refugees in the development of the policy for integration (State Agency for Refugees with the Council of Ministers, 2005)

is critical to the success of such a policy and must be respected. It is advisable that the integration programme also be expanded to include asylum seekers. The benefits of successful social integration cannot be overstated and the earlier this process is begun, the more fruitful the result.

\section{Support for independent assistance organisations}

Support for independent assistance organisations is a crucial step towards a successful policy, especially in terms of working with less visible or potentially vulnerable populations hesitant to approach government agencies. ${ }^{23}$ The provision of independent legal and other assistance to these populations needs to be facilitated and widely

21 This figure was presented in an informal meeting between members of the International Project on Immigration Trends and Immigrant Integration Policies for the Bulgarian Labour Market and officials of the State Agency for Refugees at their offices in December 2007.

22 It has been suggested by a refugee assistance organisation in Sofia, for example, that knowledge of Bulgarian is a requirement for acceptance to the integration programme, thereby shutting out those who most desperately need the assistance and significantly narrowing the number of actual applicants. Such a requirement serves to defeat the purpose of the programme. 
supported if integration is to be successful and the law respected (Acer, 2004; HarrellBond, forthcoming 2008). Support for such organisations strengthens democratic institutions and values social contributions to community betterment.

\section{Utilisation of the private sector and immigrant voices}

The private sector is a critical player in the discussion and needs to be encouraged to facilitate immigrant access as widely as possible within the confines of the law. Successful integration depends to a large extent on private sector initiative, and encouragement through financial relief and government initiative would have a significantly positive impact. Similarly, utilisation of immigrants' particular experience and perspective may serve to provide unique and highly successful contributions to the policy and economic development initiatives which concern them. Bulgaria has rhetorically espoused its appreciation for and commitment to the value of ethnic diversity (State Agency for Refugees with the Council of Ministers, 2005) and should work to utilise and celebrate that diversity to its advantage socially, economically and geopolitically. Similarly, appreciation and respect for the input of the Bulgarian community is essential to success.

\section{Conclusion}

Bulgaria has a long history of migration and has faced dramatic changes in approach to immigrants and emigrants over the course of the last half century. Developments away from the forced assimilation policies of the mid-1980s and into democratic and European Union institutions should be commended; however, there is much room for improvement in terms of access, respect and the treatment of foreigners on Bulgarian territory. Current access regimes are heavily tiered and hierarchically fashioned, while corresponding regulations obstruct access to all but the most privileged of immigrants and organisations, frustrating the capacity for the social and economic integration of large numbers of foreign contributors to economic and social growth. These structures demand review as the potential benefits of wider access are significant.

The detention of immigrants needs to be reconsidered or substantively regulated to ensure respect for rights. Detention costs present an economic drain and the social and economic potential of detainees (if regularised) is considerable, albeit potentially temporary. Additionally, immigrant integration procedures are not currently adequate and should be expanded beyond current capacity and restriction to refugees, thereby involving wider portions of the immigrant community including those members in the process of the regularisation of their status. Undocumented and semi-documented migrant populations necessitate attention and Bulgarian accession to international regimes for protection should be considered. Additionally, regularisation of these populations provides a number of benefits to Bulgarian social and economic development.

Finally, support for and utilisation of the private sector and independent assistance organisations, together with input from the Bulgarian and immigrant communities,

23 Undocumented immigrants, trafficked people, survivors of torture and others may, for any number of valid reasons, be hesitant to approach authority figures and government officials for crucial advice, assistance and information. 
are absolutely fundamental to the success of immigration policy in Bulgaria. The contribution made by these elements can not be over emphasised.

\section{References}

Acer, E (2004) 'Making a Difference: A Legacy of Pro Bono Representation' Journal of Refugee Studies 17: 347-366.

Amnesty International (2007) Bulgaria. Europe and Central Asia: Summary of Amnesty International's Concerns in the Region: January - June 2007 Amnesty International.

Bagatelas, W. T and J. Kubicová (2003) 'Bulgarian emigration - a closer look' SouthEast Europe Review 4: 27-36.

British Broadcasting Corporation (2006) 'Access limited for new EU nations' $B B C$ News London.

Chompalov, I (2000) 'Brain Drain from Bulgaria Before and After the Transition to Democracy' Bulgarian Research Symposium and Network Meeting 7 April 2000, Atlanta.

Constitution of the Republic of Bulgaria (1991) 39th National Assembly of the Republic of Bulgaria.

Convention Against Torture and Other Cruel Inhuman or Degrading Treatment or Punishment (1984) Geneva, United Nations General Assembly Resolution 39/46 of 10 December 1984.

Convention relating to the Status of Refugees (1951) Geneva, United Nations Conference of Plenipotentiaries on the Status of Refugees and Stateless Persons convened under General Assembly Resolution 429(V) of 14 December 1950.

Dacyl, J. W (1990) 'A Time for Perestroika (Restructuring) in the International Refugee Regime' Journal of Refugee Studies 3: 26-46.

Dmitrichev, T. F (1991a) 'Bulgaria: The Impact of Reform' (1991) International Journal of Refugee Law 3: 288-300, May.

Dmitrichev, T. F (1991b) 'Bulgaria: Political Parties and Groups' (1991) International Journal of Refugee Law 3: 273-287, April.

European Intercultural Workplace (2006) European Intercultural Workplace: Bulgaria in European Intercultural Workplace (Ed.) Sofia: European Centre for Education and Training.

European Union (2004) Table 1 - Population projections for the EU25 + Bulgaria and Romania: Total population, Eurostat.

Eurostat (2004) Table 1 - Population projections for the EU25 + Bulgaria and Romania: Total population. European Union.

Fassman, H and R. Munz (1994) 'European East-West Migration 1945-1992' International Migration Review 28: 520-538.

Foreigners in the Republic of Bulgaria Act (2006) State Gazette of the Republic of Bulgaria: Sofia. 
Harrell-Bond, B (forthcoming 2008) 'Starting a Movement of Refugee Legal Aid Organizations in the South' International Journal of Refugee Law 19: 729-735.

Helton, A (1992) 'Ten Case Abstracts' International Journal of Refugee Law 4: 381392.

Hershman, G (2007) 'The Other Expats: Bulgaria's forgotten foreigners languish in limbo and the state seems indifferent' Vagabond.

Home Office of the Government of the United Kingdom (2006) Controlled Access To UK Labour Market For New Accession Countries.

Hughes, J and F. Liebaut (1998) Detention of Asylum Seekers in Europe: Analysis and Perspectives Leiden: Martinus Nijhoff Publishers.

Ilareva, V (2007a) 'Immigration Detention in International Law and Practice: In Search of Solutions to the Challenges Faced in Bulgaria' Statewatch.

Ilareva, V (2007b) 'Bulgaria's treatment of asylum seekers' Forced Migration Review 29: 60-61.

International Convention on the Protection of the Rights of All Migrant Workers and Members of their Families (2003) Geneva, adopted by United Nations General Assembly Resolution 45/158 of 18 December 1990.

Krasteva, A (2006) 'Post-communist discovery of immigration: the case of Bulgaria' South-East Europe Review 2: 25-34.

Law on Entering, Residing and Leaving the Republic of Bulgaria of European Union Citizens and Members of their Families (2006) State Gazette of the Republic of Bulgaria: Sofia.

Law on Bulgarian Identification Documents (2007) State Gazette of the Republic of Bulgaria: Sofia.

Law on Foreigners in the Republic of Bulgaria (2007) State Gazette of the Republic of Bulgaria: Sofia.

Law on the Encouragement of Employment (2007) State Gazette of the Republic of Bulgaria: Sofia.

Law on Fighting the Illegal Traffic of People (2005) State Gazette of the Republic of Bulgaria: Sofia.

Law on Protection Against Discrimination (2004) State Gazette of the Republic of Bulgaria: Sofia.

Law on Asylum and Refugees (2002) State Gazette of the Republic of Bulgaria: Sofia.

Law on Bulgarian Citizenship (1989) State Gazette of the Republic of Bulgaria: Sofia.

Loizos, P (1999) 'Ottoman Half-Lives: Long-term Perspectives on Particular Forced Migrations' Journal of Refugee Studies 12: 237-263.

Markova, E and B. Reilly (2006) 'Bulgarian Migrant Remittances and Legal Status: Some Micro-level Evidence from Madrid' Sussex Migration Working Paper No. 37 University of Sussex: Sussex Centre for Migration Research. 
Mintchev, V (1999) 'External Migration and External Migration Policies in Bulgaria' South-East Europe Review 2: 123-150.

Petkov, S (2007) 'Debate: is there a legal deficit in detention centres for foreigners?' Obektiv.

Skran, C. M (1998) 'Profiles of The First Two High Commissioners' Journal of Refugee Studies 1: 277-296.

State Agency for Refugees with the Council of Ministers (2005) National Programme for Integration of Refugees in 2005-2007 http://aref.government.bg/?cat=25.

Treaty Concerning the Accession of the Republic of Bulgaria and Romania to the European Union (25 April 2005) Luxembourg.

UNHCR BO Sofia (2002) Bulgaria Country Operations Plan 2003 The United Nations High Commissioner for Refugees: Sofia.

Universal Declaration of Human Rights (1948) Geneva, adopted and proclaimed by United Nations General Assembly Resolution 217A(III) of 10 December 1948.

Vassilev, R. V (2001) 'Post-Communist Bulgaria's Ethnopolitics' Global Review of Ethnopolitics 1: 37-53.

Wolton, S (2000) 'Conference and Symposium Reports: "Barbed Wire Europe: Conference against Immigration Detention"' held in Ruskin College, Oxford, 15-17 September 2000, Journal of Refugee Studies 13: 415-423.

\section{Appendix: Articles 24 and 25 of the Law for Foreigners in the Republic of Bulgaria, regulating non-EU citizen access to extended stay and the labour market (official translation)}

\section{Art. 24.}

(1) (amend. - SG 29/07) A permission for long stay shall be able to receive foreigner who have a visa under Art. 15, para. 1 and:

1. (Amend., SG 42/01; amend., SG 112/01) wish to work under legal terms of employment upon permit by the bodies of the Ministry of Labour and Social Policy;

2. (Amend., SG 42/01; suppl., SG 37/03) carry out commercial activity in the country according to the legally established order, and as a result of this activity at least 10 positions have been opened for Bulgarian citizens, unless agreed otherwise by an international agreement, ratified, promulgated and enacted in the Republic of Bulgaria;

3. are admitted to regular education in licensed educational establishments;

4. are foreign specialists staying in the country by force of international agreements to which the Republic of Bulgaria is a party;

5. (amend. - SG 29/07) have grounds to have permitted permanent stay or have married with a foreigner with permanent stay in the country;

6. (Amend., SG 42/01) are representatives of foreign commercial companies registered at the Bulgarian commercial - industrial chamber;

7. (suppl., SG 37/03) are financially ensured parents of foreigners with permanent stay in the country or of a Bulgarian citizen;

8. (amend., SG 70/04) have started long treatment in a medical establishment and dispose with financial resources for healing and maintenance; 
9. are correspondents of foreign mass media and have accreditation in the Republic of Bulgaria;

10. are pension ensured and dispose with sufficient resources for maintenance in the country;

11. (amend., SG 37/04) implement activity under the Law for encouragement of investments;

12. implement activity by order and request of persons who have made investments in the country by the order of the Law for the foreign investments;

13. (Amend., SG 42/01) are members of the family of a foreigner who has received a permission for long stay;

14. (New, SG 42/01; amend., SG 37/03, amend., SG 63/05 - in force from 01.01.06; amend. - SG 29/07) are parents of a foreigner or live in concubinage with a foreigner who has obtained a permit for continuous stay on the grounds of Art. 22, para 3;

15. (New, SG 42/01; amend., SG 112/01) wish to carry out free-lance practice upon permit by the bodies of the Ministry of Labour and Social Policy in compliance with art. 24a;

16. (New, SG 112/01) wish to carry out non-profit activity upon permit of the Ministry of Justice under conditions and by an order determined by an ordinance of the Minister of Justice, in coordination with the Minister of Interior;

17. (new - SG 29/07) have acquired statute of special protection as per Art. 25 of the Law of Fighting the Illegal Traffic of People;

18. (new - SG 29/07) are members of the family of a Bulgarian citizen under Art. 2, para 2.

(2) The persons of para 1 shall have ensured home, maintenance, obligatory insurances and insuring according to the legislation of the Republic of Bulgaria. The normatives for this shall be determined with an act of the Council of Ministers.

(3) (new - SG 63/05, in force from 01.01.06) the requirement under Para 1, item 2 for opening of at least 10 working positions shall not refer to citizens of the Member States of the European Union, as well as to citizens of the other Member States of the Common European Economic Space.

Art. 24a. (New, SG 42/01; amend., SG 112/01)

(1) (suppl., SG 37/03) A foreigner who wishes to stay continuously on the territory of the Republic of Bulgaria with the purpose of carrying out free-lance activity can obtain a visa for continuous stay or a permit for continuous stay if he meets the legally established requirements for entry and stay in the country, presenting to the diplomatic and consular representations, respectively to the offices for administrative control of the foreigners, the following documents:

1. application in a form;

2. permit for carrying out free-lance activity.

(2) The permits for carrying out free-lance activity shall be issued by the bodies of the Ministry of Labour and Social Policy.

(3) The conditions and the order of issuance, refusal and revoking permit for carrying out free-lance activity by foreigners shall be determined by an ordinance to be issued by the Minister of Labour and Social Policy in coordination with the Minister of Interior and the Minister of Finance. 
(4) Not issued shall be visa for continuous stay for the purpose of carrying out freelance practice to a foreigner in the cases under Art. 24, para 1, item 1 - 13 and 16.

(5) Foreigners who meet the legally established requirements for carrying out the respective free-lance activity shall be released from the requirement for issuance of permit if this is stipulated by an international agreement party to which is the Republic of Bulgaria.

Art. 25. A permission for permanent stay shall be possible to receive the foreigners:

1. of Bulgarian ethnic origin;

2. (amend. - SG 29/07) five years after the marriage with a foreigner staying permanently in the country;

3. (amend. - SG 29/07) small or below age children of a foreigner with permanent stay in the country and who have not been married;

4. (Amend., SG 42/01) parents of Bulgarian citizens when they provide the due legally established support, and in the cases of acknowledgement or adoption upon expiration of 3 years from the acknowledgement or adoption;

5. (amend. - SG 29/07) stayed on legal grounds without interruption on the territory of the country during the last 5 years, provided that in the cases under Art. 24, para 1, item 3 only half of the term of stay shall be recognised;

6. (amend., SG 11/05) invested in the country over 500000 US\$ by the lawful order;

7. (New, SG 42/01) who are not persons of Bulgarian origin, born on the territory of the Republic of Bulgaria, lost their Bulgarian citizenship according to emigration agreements or by their own wish and they wish to settle permanently on the territory of the country.

8. (new, SG 37/03) who, by December 27, have entered, stay, or were born on the territory of the Republic of Bulgaria, and whose parent has married a Bulgarian citizen;

9. (new - SG 29/07) members of the family of the Bulgarian citizen, if they have stayed continuously in the territory of the Republic of Bulgaria during the previous five years.

Art. 25a. (New, SG 42/01)

Permit for stay in the Republic of Bulgaria, without the presence of the requirements of this law can be obtained by foreigners who have contributions to the Republic of Bulgaria in the public and economic sphere, in the sphere of the national security, science, technology, culture or sport. 